The International Journal of Banking and Finance, Volume 9 (Number 3), 2012: pages 46-68

\title{
DETERMINANTS OF OFF-BALANCE SHEET BUSINESS IN THE CASE OF GCC BANKING SECTORS
}

Mohammad Elian

Gulf University for Science and Technology, Kuwait

\begin{abstract}
This paper identifies the association between off balance sheet businesses and a number of determinants identified for the banking sectors of the Gulf Cooperation Council countries. The Fixed Effects Least Squares Dummy Variable Model is used to identify the determinants for a large sample of 64 banks over a recent fifteen-year period. The results reveal that bank-specific variables have important roles in influencing off balance businesses. As for the regulatory variable, capital items are less important, which is contrary to the long-held market discipline hypothesis, under which secure banks are predisposed to engage in more off balance businesses. The macroeconomic variable reveals that higher real GDP growth does not necessarily cause an increase in the off balance activities. However, its positive impact indicates that the off balance business actions follow business cycles, and the overall growth of economy. Prudential regulators, as a policy matter, need to consider region-wide implications of these findings. This is important given the fact that regulating how off balance business is conducted in the region would influence costs and the scope of banks, hence also the monetary policy.
\end{abstract}

Key words: Off-balance sheet, regulatory pressure, macroeconomic conditions, GCC.

JEL Classification: C33, F65, G21

\section{Introduction}

For the last three decades, banking products have gone deeply into transformations in the face of a wide range of financial innovations that are viewed as critical for economic growth. These innovations, in conjunction with securitization and financial derivatives, include a considerable expansion in range and scope of the fee-based forms, off-balance sheet (OBS) businesses which causes a shift from traditional intermediary credit functions to more marketable credit 
instruments. As a result, banks have offered a wide spectrum of OBS forms by originating financial contracts that result in the acquisition of certain assets and liabilities with contingent conditions, which is enters as off balance sheet (OBS) businesses. This paper investigates this phenomenon in the banking sectors in the Gulf Cooperation Council (GCC) countries.

For banks, the expansion toward OBS businesses allow them to downsize their on-balance sheet items by generating additional fee income to offset size reduction of interest rate margins generated from banks' granting loans. Other motivational factors include global trade relations, hedging and reducing (or avoiding) regulatory restrictions i.e., reserve requirements, capital and deposit insurance premiums that are not imposed on OBS businesses. On the contrary, other parties - regulators, securities analysts and economists - raise a major concern regarding the risk to the banking sector associated with such contingent claims-based business activities that magnifies leverage, causing more overall risks for banks: interest risks, credit risks and liquidity risks as pointed out in Bennett (1986). Further, given the current financial deregulation environment worldwide, banks have expanded their risk-taking levels, causing more failure cases in the marketplace.

It is very obvious that OBS businesses have both risk-increasing and risk-reducing attributes where increased OBS earnings can potentially compensate for increased OBS exposure. It may even actually reduce the probability of insolvency for most financial firms. Nevertheless, OBS activities have the potential to seriously harm the banks when major crisis occurs. Recall the parallel banks that provided US\$12 trillion capital to the US banking sector and the collateralized debt obligations as off balance items were the two root causes of the 207-8 Global Financial Crisis (Ariff et al., 2012).

As empirical literature, several studies of OBS business are available, though these are confined to developed banking markets in the US, Europe and some economies in Asia. In Asia, the phenomenon is most prevalent even though a limited evidence is forthcoming for emerging banking markets (see Jagtiani et al 1995a, b; Fung and Cheng, 2004 and Nachane and Saibal, 2007). Therefore, while a systematic test of OBS businesses in the context of emerging markets seems to be a reasonable justification, this paper bridges this gap in literature by testing within 
the GCC countries. ${ }^{1}$ In particular, it is an useful study since prudential regulators of this group of countries act in unison as region. These regulators may benefit from this dissemination of our findings.

As for methodology, a bank level panel data estimation technique is used. This allows identifying and measuring effects that are simply not demonstrable in cross sections or timeseries analysis. The results of the panel data estimates reveal that bank-specific variables have an important role influencing OBS businesses. The results show insignificant influence of the regulatory as well as the macroeconomic variables.

The present study contributes to the above literature by exploring the usage of OBS businesses and testing for its determinants within the GCC. The focus on the GCC banking industry is justified by the following attributes. First, with more deregulation, the market risk facing banking decisions are augmented in the light of the risky scheme of lending that causes growing integration need with most regional/global counterparties. Simultaneously, the usage of hedging instruments has become crucial. Second, given the global as well as the regional competitions and the reduction in interest income, GCC banks began to compete through the usage of non-interest sources of income.

Third, the policy initiatives that have been provided by the regulatory authorities following the reversal of speculative capital inflows that cause the banking industry to face severe squeezed liquidity conditions. Such liquidity positions started to tighten in the beginning of the year 2008, reflecting an increasing reliance on external financing. Hence, the record low liquidity ratio reflects relatively high asset-liability maturity mismatch in the GCC banking, calling for more off balance sheet items to be issued for hedging purposes. Fourth, the fluctuation in oil prices creates unstable cash flows and, hence, volatile liquidity conditions: see Hassan et al (2010).

The rest of the paper is structured as follows: Section 2 provides a brief review of the related literature. Section 3 presents the methodology, specification of tests and data collection, while

\footnotetext{
${ }^{1}$ The Gulf Cooperation Council (GCC) includes Saudi Arabia, Kuwait, Qatar, United Arab Emirates, Oman and Bahrain. These countries share common culture, language, religion, and all are considered as oil producing countries and facing nearly similar deregulation and risks environment.
} 
section 4 describes the data and its empirical findings. Concluding remarks are given in section 5.

\section{Literature on Innovation Adoption and OBS}

Worldwide a downward trend in granting loans by traditional banking businesses occurred in recent decades, which is attributed to economic changes, financial innovations, and relaxation of restrictions as de-regulation took center stage. This trend led to an expansion of businesses toward non-interest services, specifically OBS businesses. It seems that the growth of the OBS businesses in the late 1970s and 1980s was a natural response to clients' demand for credit guarantees and interest rate insurance at that time of high inflation and thus high interest rates.

Overall, the literature suggests a downward trend of traditional businesses and the expansion of the OBS usage. Boyd and Gertler (1994) stress the financial innovations as a major cause of the downward trend of traditional banking businesses, while Edwards and Mishkin (1995) justify the drop in such businesses to the economic forces. They show the bank's declining importance as a source of funds to non-financial borrowing clients, increased activities toward asset securitization, growth of commercial papers and junk bond markets, increase in financial services provided by non-bank intermediaries. The result was reduced bank spreads, costs and income advantages causing reasonable incentives to justify a bank to involve in the OBS businesses.

Siems and Clark (1997) reveal the emergence of new forms of intermediation. The expansion toward fee-based businesses have been stimulated by several factors, which include changes in fundamental economics, technological progress, along with changes in the surrounding political enforcements. Angbazo (1997) argues that, due to primarily the increased volatility in both interest rate and foreign exchange rate markets, banks started to provide numerous risk management services that were tailored to specific needs of their clients. Such practice was targeted in order to strengthen client relations in order to capture additional noninterest income through fee-based contingent claims securities trading. 
Hassan and Sackley (2002) identify, for the 1980s and early the 1990s, the banking industry faced numerous changes in the overall financial environment in highly volatile conditions ${ }^{2}$ causing banks to expand their OBS businesses as alternative sources to secure returns for banks. Khambata and Bagdi (2003) ascribe the growth in OBS businesses to factors that include competition, market pressures and volatility in the market forces, movements toward deregulation, informational innovations and advancement in technology, lower levels of profitability from the traditional on-balance sheet banking businesses. They also include a desire to minimize the degree of risk linked with such businesses or with expansion of the investment opportunities to secure higher returns required by investors.

On the issue of determinants of OBS businesses, Pavel and Philis (1987) examine the determinants of loan sales of commercial banks. They conclude that diversification, capital, binding capital and reserve requirements have important influences on loan sales, suggesting that banks should and will start to sell loans when capital ratios are low and charge-offs are high. They conclude that banks with binding capital constraints are more likely to engage in OBS business, swaps and loan securitization, than banks with excess capital. This result is supported by Baer and Pavel (1987), who assert that banks normally are involved in loan securitization and standby letter of credits (SLCs) to avoid breaching regulatory requirements, namely reserve constraints and deposit insurance premium.

However, Benveniste and Berger (1987) and Koppenhaver (1989) argueed that binding capital requirements are not significant influential factors toward issuing SLC guarantees. Koppenhaver (1989) states that bank size, reserves, and loan losses are the main determinants of banks expanding OBS business. Similar results are reported by Kaufman and Mote (1994): banks may engage in their normal businesses more efficiently and may even grow more rapidly under alternative regulatory regimes, particularly those regimes that allow for expansion across state lines and do not restrict banks to commercial and investment businesses.

\footnotetext{
2 These conditions include changes in the financial market forces fluctuated economic conditions, highly competitive local and international pressures, movements toward deregulation, new capital adequacy requirements, progressed technology in communication and data processing, diminishing returns that normally generated from onbalance sheet businesses.
} 
Sinha (2005) identifies that OBS businesses are positively related to operating profit ratio and negatively with the non-performing ratios. Nachane and Ghosh (2007) have us believe not only regulatory factors but also market forces are at work in the diffusion pattern of OBS businesses. They show that non-performing assets and bank size are of prime concern for foreign as well as public sector banks. Ahmad and Hassan (2010) suggest there exists an informational economy of scope between loan and OBS businesses that is profit driven. They conclude that banks participate in more OBS businesses to reduce risk resulting from granting loans, while it is true political and economic events negatively affect banks OBS businesses.

\section{Methodology Specification and Data Collection}

\subsection{Model Estimation}

Several econometric models are available and may be used as empirical models to form the basis for examining the OBS businesses in the banking industry. As for GCC, the standard diffusion model developed by Mansfield (1961) is appropriate. This model is the most commonly used model in diffusion studies: Hannan and McDowell (1984); Jagtiani et al (1995a); Bondt (1997); Nachane and Saibal (2007); and Ahmad and Hassan (2010).

The basic proposition is that for the proportion of banks not adopting an OBS item at time $(t)$, their adoption begins at time $(t+1)$. This is a function of the proportion of those adopters at time $(t)$. Based on such a premise, the growth in the proportion of banks adopting the OBS innovation over time may be expressed as the logistic function:

$$
\mathrm{X}_{t+1}-\mathrm{X}_{t}=\beta\left(\mathrm{T}-\mathrm{X}_{t}\right) \mathrm{X}_{t} / \mathrm{T}
$$

Where $X_{t}$ is the total or cumulative number of banks adopting an OBS item by time $(t)$ and $(T)$ is the total number of banks in the banking industry. $\beta$ is the parameter which can measure the rate of the OBS diffusion across banks. Replacing discrete time by continuous time and integrating produces a logistic time cure describing OBS diffusion: 


$$
\mathrm{X}_{t} / \mathrm{T}=\frac{1}{\{1+\exp (-\alpha-\beta t)\}}
$$

While $\mathrm{X}_{t} / \mathrm{T}$ is the proportion of banks adopting the innovation (issuing an OBS item) at time $(t)$, $\alpha$ and $\beta$ are the parameters which measure the rate of diffusion. ${ }^{3}$ The expected value of $\beta$ can be assumed to be a function of innovation (industry) characteristics. Generating $\beta$ through OLS estimation is considered a standard practice. This can be achieved by Equation (2) in its revised form and then by regressing the resulting estimates of $\beta$ on the chosen firms-specific and innovation-specific variables as influences on the rate of diffusion: Hannan and McDowell (1984). Overall, given a relevant transformation and the panel structure of the data, the basic equation to be estimated can be as follows:

$$
\operatorname{InOBS}=\operatorname{In}\left(\frac{P(i t)}{(1-P(i t))\}}\right)=\alpha i+\beta t+\varepsilon i t
$$

$P_{i t}\left(\mathrm{X}_{t} / \mathrm{T}\right)$ is the proportion of bank $(i)$ issuing an OBS item at time $(t)$ relative to the total asset size of bank $(i)$ at time $(t)$, including total of on-balance sheet items and off-balance sheet items of bank (i) at time $(t)$. Following Jagtiani et al (1995) and Bondt (1997), the justification for this is that we consider the scale on which banks issue an OBS items is a linear relationship between the number of banks engaged in issuing OBS as a proportion of all banks and the amount of OBS items in terms of the total balance sheet size (on and off-balance businesses).

In light of the aforesaid discussion and depending on the characteristics of the unobservable bank-specific variables, $\alpha_{i}$, the researcher needs a two way error component regression model, which can be outlined. More specifically, pooled regression data model presupposes the fact that differences across units can be captured in differences in constant term (as for the fixed effect

\footnotetext{
${ }^{3}$ The S shaped diffusion curve of equation (2) expects that the proportion of banks adopting OBS items will move upwards at an accelerating bound until a proportion of 50 per cent of total banks is attained at time $\mathrm{t}=-(\alpha+\beta)$. Hence, OBS adoption would move up at a decreasing bound, and 100 per cent OBS diffusion is loomed asymptotically, see Morrison (1996), Bondt (1997) and Nachane and Saibal (2007).
} 
modes) or alternatively, as individual specific constant terms are randomly distributed across cross-sectional units (as for the random effects models). The fixed effects model as a method for pooling time-series cross sectional data considers all individual differences as captured by differences in the intercept parameter. The intercepts $\left(\alpha_{i}\right)$ were considered as fixed parameters that we could estimate directly using the least squares estimator. The fixed model assumes that the errors $e_{i t}$ are independent with mean zero and constant variance $\sigma_{e}{ }^{2}$, for all individuals and in all time periods. Following that, all behavioral differences between individual firms and over time are captured by the intercept. Where the individual intercepts are there to control for the firm-specific differences. The resulting econometric model is:

$$
y_{i t}=\alpha_{i}+\beta_{1} X_{1 i t}+\beta_{2} X_{2 i t}+\beta_{3} X_{3 i t}+\beta_{4} X_{4 i t}+\ldots \ldots \ldots+\beta_{N} X_{N i t}+e_{i t}
$$

For the random effect model, even it assumes that all individual differences are captured by the intercept parameters, considers the individual differences as random rather than fixed. The random model considers $\alpha_{i}$ as mutually independent random variables that are independent of the equation's error term. Thus, the constant term model $\alpha_{i}$ is a separate constant term for each bank: $\alpha_{i}=\alpha_{1} \mathrm{~d}_{1+} \alpha_{2} \mathrm{~d}_{2} \ldots \ldots$, with the $\mathrm{d}_{\mathrm{j}}$ 's bank-specific dummy variables. In other words, the random individual differences can be included in the econometric model by specifying the intercept parameters $\alpha_{i}$ to consist of a fixed part that represent the population average and random individual differences from the population average, $u_{i}$. So, in the random effects model $\alpha_{i}$ is a firm-specific disturbance: $\alpha_{i}=\alpha+u_{i}$. The random individual differences $u_{i}$ which are called random effects, are analogous to random error terms that have zero mean, uncorrelated across individuals and have a constant variance $\sigma_{u}{ }^{2}$, so $E\left(u_{i}\right)=0, \operatorname{cov}\left(u_{i}, u_{j}\right)=0$ and $\operatorname{var}\left(u_{i}\right)=\sigma_{u}{ }^{2}$.

For this research, while the data set exhausts the population, there is an earlier argument supporting the hypothesis that bank-wise variances in performance derived from divergences in initial terms/conditions such as scale of operations, indicates there are bank-specific constants. That in turn supports the choice of the fixed effect estimator: Nachane and Ghosh 2002). In other words, while we are not drawing $N$ individuals (banks) randomly from a large population, the focus, in the present study, is on a specific set of firms (banks in our case) and the inference is 
restricted to the behavior of these firms (banks), so the use of the fixed effects model is appropriate: Bondt 1997 and Baltagi (2008). ${ }^{4}$

However, while there is no prior condition to suggest correlation between the cross-sectionspecific error component $\left(\varepsilon_{i}\right)$ and the regressors (explanatory variables), hence panel data test could also be estimated as the random effects model in which substantial differences between the FEM and REM is concluded. ${ }^{5}$ The Hausman test is used to compare the coefficient estimates from the two models, to make the decision as to which model is more appropriate. ${ }^{6}$ To conclude, the used model in this article is an extension of the earlier basic model presented in Equation (3) above. These variables are bank-specific variables (characteristics) in addition to regulatory and macroeconomic explanatory variables. Accordingly, the empirical test is based on the following general pooled regression equation that typifies a modified version of Equation (3):

$$
\operatorname{In} O B S=\operatorname{In}\left(\frac{P(i t)}{(1-P(i t))\}}\right)=\alpha i+\beta t+\phi i \mathrm{t}+\varphi \mathrm{it}+\varepsilon i t
$$

$i$ denotes the number of banks $(i=1,2,3, \ldots \ldots . ., 64)$ and $t$ denotes the number of years $(t=1,2,3, \ldots \ldots \ldots \ldots, 15) . \operatorname{InOB} S_{i t}$ (as logistic transformation of $\left.P_{i t}\right)$, is the dependent variable and represents the proportion of bank $(i)$ issuing OBS items at time $(t)$ relative to the total asset size of bank $(i)$ at time $(t)$, including total of on-balance sheet items and off-balance sheet items of bank $(i)$ at time $(t)$. The time trend $(\beta t)$ accounts for the autonomous diffusion (deterministic trend), where its coefficient of indicates the autonomous speed of OBS diffusion. $\phi_{i t}$ is a function defining bank $(i)$ specific variables (creditworthiness variables) at time $t \cdot \varphi_{i t}$ is a function defining bank $(i)$ nonspecific variables at time $t$. $\varepsilon_{i t}$ : is the residual term that is included to reflect all other influences on bank $(i)$ 's probability to issue OBS items.

\footnotetext{
${ }^{4}$ In the case where $N$ is large, a fixed effects model would lead to an enormous loss of degrees of freedom, causing the need to use the random effects model rather than the fixed effects model.

${ }^{5}$ Statistically, if it is assumed that $\varepsilon_{i}$ and the regressors are uncorrelated, REM may be recommended, but if they are correlated, then, the FEM would be more appropriate.

${ }^{6}$ The null hypotheses underlying the Hausman test is that FEM and REM do not differ substantially.
} 
For our case, the bank-specific variables include market power, bank size, loan ratio, net loan ratio, net loan charge-offs and profitability. The bank nonspecific variables include the capital adequacy ratio and the growth in real gross domestic product in order to proxy regulatory and macroeconomic condition variables, respectively.

\subsection{Proxies of Variables}

The dependent variable $(O B S)$ is measured by the natural logarithm of bank (i) OBS items at time $t$. The time trend variable (TIME) indicates the number of years since the first year of the sample period. Its coefficient reflects the autonomous speed of diffusion $(\beta)$, which depends on development in financial technology, learning factors and changing preferences regarding the OBS produced items. Larger $\beta$ indicates more rapid adaptation of an OBS product, Bondt (1997).

For market power (MARP), it is expected that the more market power a bank has, the more the bank has ability to expand businesses toward on-balance sheet and off-balance sheet businesses. While market power increases, the creditworthiness of a bank is expected to have a positive impact on the probability of banks to underwrite an OBS item. For measurement purposes, the level of market share (the percentage share of bank (i) deposits to total bank deposits) is used as a relevant statistic to provide a snapshot of the market power at a point in time. This ratio measures the absolute size of total deposits which is held by the $i^{\text {th }}$ bank relative to total size of the banking market as measured by total deposits. So, although the market power of bank ( $i$ ) is assumed to be directly related to the bank share of the deposits market, the MARP coefficient is expected to be positive, indicating that bank with more market power tends to engage in more OBS businesses.

For the bank size (BSIZ), the impact on OBS businesses can go either way (positive/negative). On the one hand, large size banks, in terms of total assets for example, will have more chance to diversify their banking businesses, employ high skilled and well trained employees, derive the benefits of the economies of scale, and be more efficient in providing higher quality services. Large banks may also have well developed and widespread networks with access to large and sophisticated clients who are likely to be asking for OBS products. 
Further, large banks armed with specialized management skills will ask for and move toward more OBS products engagement, thus meeting the demand for large and institutional clients who, on the other hand, will be in favor to of engaging large banks to handle their OBS demand.

In addition, greater market confidence is normally directed to large banks, causing less failure possibility. Such indicators, along with others, will encourage banks to expand their businesses toward the OBS items, keeping in mind that OBS businesses may require that a bank be of a certain size in order to realize economies of scale or to use qualified management skills needed for OBS products. On the other way around, it can be argued that larger banks in terms of total assets would have the probability to be more risk-diversified (less business risk) causing less usage of an OBS product. In this study, a relevant proxy is the natural log of total assets for BSIZ: the coefficient is expected to be positive/negative.

The loan ratio (LOAR) is measured as loan to total assets. As reported by Angbazo (1997), higher loan ratio normally increases interest rate risk, leading to more engagements in OBS businesses for hedging purposes. Another rational to support such expected impact, as mentioned by Nachane and Ghosh (2007), lies in the way it is used. Approving clients' loans in which banks access their clients' investment information, will facilitate the decision on the offer of relevant OBS risk management products. While the LOAR is directly related to OBS businesses, its coefficient is expected to be positive, indicating that banks with more loan ratio tend to undertake more OBS businesses.

The net loan ratio (NLOR), which is measured as gross loan minus loan loss reserves as a percent of total assets. This can be regarded as a measure of the maturity gap and maturity mismatch between a bank assets and liabilities. As net loan ratio widens, the maturity gap widens as well, providing a positive incentive to use OBS products since the increase in risk exposure has to be hedged. Banks with more willingness to make risky loans may be more willing to take more OBS risk (Bondt 1997). The coefficient is expected to be positive, indicating that bank with more net loan ratio tend to undertake more OBS businesses.

For the net charge-off ratio (NCHR), the impact is ambiguous. On the one hand, considering the net charge-off as a proxy of non-performing loans, the impact is expected to be negative. An 
increase in a bank's non-performing loans would decrease its creditworthiness, leading to lower levels of OBS practices. On the other hand, higher levels of a bank charge-offs indicate higher levels of loan portfolio risk, reflecting the increased possibility of issuing or supplying OBS products for hedging purposes. This would also simultaneously generate substitute income (fee income) to compensate for bad debt loans. Hence, an increase in the level of charge-off would have a positive impact on issuing an OBS product. The charge-offs (net loan write-offs) which are based on the difference between loans actually written-off and recoveries on loans previously classified as uncollectable, to gross loan ratio is used as a proxy of the NCHR variable.

The impact of the profitability (PROF), measured using net income from intermediation profitability, can be positive or negative. On the one hand, profitability cab be considered as a measure of a banks' creditworthiness and indicates a clients' trust, causing anticipated positive relationship between profitability and the issue of OBS items. Further, high profits increase cash flows, which can be retained to absorb future loses to reflect the chance to improve creditworthiness. Banks with more creditworthiness would attract or would use more of OBS businesses. This is supported by the argument that more profitability is an indication of superior management armed with optimal utilization of bank assets and of higher productivity that produces lower costs, reflecting an improvement in the interest spreads.

On the other hand, banks with low net income would attempt to increase their underwriting in fee-based forms of income to offset reduced interest income generated from traditional credit businesses. Hence such banks would supply more derivatives (OBS) products. Keeping in mind those banks with high net interest income would lock in their interest spreads by using derivatives to hedge. The moral hazard hypothesis suggests that banks with low net interest income (low profitability) would speculate using derivatives, while banks with high net interest income will not hedge, reflecting lower usage of OBS products.

As for non-bank-specific variables, the capital adequacy ratio and the growth in real gross domestic product are included as controls for regulatory and macroeconomic conditions respectively. For the banks' capital adequacy ratio (CAPC), the impact is ambiguous and can be viewed differently (Furlong and Keeley, 1989; cited by Bondt, 1997; Nachane and Ghosh, 2007; and Ahmad and Hassan, 2010). While the capital adequacy ratio (CAR) measures the banks' 
capital to protect its depositors and insure stability, OBS businesses are expected to be larger for banks with higher CAR ratio since these banks are more creditworthy therefore clients would place more trust towards the performance of such banks. A high CAR with accompanying high credit rating would be an incentive for a bank to be an attractive provider/supplier of OBS products.

Alternatively, a high CAR ratio reduces a banks' marginal gain from increasing the risk in the asset portfolio. As bank capital increases, the ability to assume/bear risk increases as well, but the need for OBS products to hedge the risk exposure may decrease. Therefore, a bank with high CAR could also be expected to take on less OBS risk and issue a lower volume of OBS item/products. The capital adequacy ratio is used as proxy for capital. ${ }^{7}$

Variables included in the tested model, their expected sign, and economic rationale all are shown in Table 1.

\section{Table 1: Variables in the empirical model}

\footnotetext{
${ }^{7}$ The emphasis is on the response of banks to the $8 \%$ total risk-based capital standards which signals to the degree of regulatory pressure for adequately capitalized banks, CAR more than 8 per cent. Banks in the GCC region have acceptable leverage ratios and are well capitalized with capital adequacy ratios (CAR) above the minimum standard levels of the CARs
} 
The effect triggered by variations in the economic activity is captured by the real gross domestic product growth rate (GROR) which is used to control for the macroeconomic conditions. Under high growth rates of GDP, demand for OBS products will respond positively taking into consideration the growth in the business cycles. The variable coefficient is expected to be positive, reflecting that with the higher growth rates of GDP and the probabilities of issuing OBS items will increase.

\subsection{Data Collection}

The published source of data in emerging markets rarely provides satisfactory data to commence panel data investigation. Considerable efforts were needed to construct the targeted size of panel database using Bank Scope and the IMF data sources. The growth in real GDP variable is obtained from the International Financial Statistics (IFS) online database. To prepare the sample, we include all banks over the sample period reflecting a total balanced panel of 64 banks drawn from Bahrain, Kuwait, Oman, Qatar, United Arab Emirates and Saudi Arabia. To avoid outliers, the filtering process eliminated short lived banks, foreign banks and central banks. Overall, to estimate the empirical version of the model, the pooled data sample includes a total of 7,680 annual observations over 15 years.

The period represents an era of significant challenge to the GCC banking industry in which banks have been attempting to improve and measure their performance while facing several changing economic conditions such as regulation, high inflation, volatility in oil prices, volatility in interest rates, high variability in structuring and pricing derivatives worldwide, volatility in foreign exchange rates against currencies other than the US dollar, and the reduction in demand for some exports, in addition to the effect of deregulation, competitive pressures and increased uncertainty about returns compared with the 1980s. One may add that this period is of particular interest given the debate between regulators about OBS businesses and capital requirement. Further, this period spans the years prior to and after the global financial crises. 


\section{Empirical Findings}

Before embarking on presenting the empirical findings, it is worth mentioning that the OBS businesses display a wide variation over the period. This is not surprising since most banks are relatively new participants in OBS items. Given the standard classification of Bank-scope data base, OBS businesses include (a) Managed securitized assets, (b) Other OBS exposure to securitization, (c) Guarantees, (d) Acceptances and documentary credits, (e) Committed credit lines, (f) Other contingent liabilities. ${ }^{8}$ Yet, 25 per cent of banks have reported their usage of guarantees, 18 per cent for acceptances and documentary credits, 19 per cent for committed credit lines, and 39 per cent for other contingent liabilities. Managed securitized assets and other OBS exposure to securitization are not reported by the GCC banks as OBS items under usage.

The limited usage of the OBS businesses indicates that the banking sector in the GCC region still relies on the traditional banking businesses as the main source and use of funds. ${ }^{9}$ So far, most banks assets portfolios are composed of loans, securities investments, and Islamic finance products. Given such asset structures, during the financial crises, GCC banks faced significant losses through mark-to-market valuations of their trading portfolios, keeping in mind that those banks in the GCC held 18 per cent of their portfolios in securities as at the end of 2008 while only 1 per cent was held in derivatives: Hassan et al., 2010. Overall, it seems that a reasonable levels of profitability was generated from on balance sheet activities, in conjunction with the low volatile conditions. Both interest rate and foreign exchange rate markets caused less incentives for OBS businesses as alternative sources of returns.

\footnotetext{
${ }^{8}$ For categorization purposes, OBS businesses can be categorized into two categories. First, those businesses that generate income or expenses without the creation or holding of underlying asset or liability (market related activities) i.e., when a bank acts as a broker (taking a fee for arranging for funds to be provided to borrowers without making loans or raising deposits), rather than as a dealer (making and holding loans and any other funding sources. Another example is providing banking services, such as cash management, that generate income without requiring assets or liabilities. Second, those businesses that involve the bank's commitments and contingent claims, which might be grouped to the following: (1) Financial Guarantees i.e., standby letter of credit, line of credit, revolving loan agreement, securitization of asset with re-course, and note issuance facilities such as Euro-notes, revolving underwriting facilities (RUFs), and standby notes. (2) Trade Finance i.e., commercial letter of credit, acceptance participation, and investment activities that includes all derivative instruments such as forward commitments, financial futures, interest rate swaps, option (put, call, collars), and currency swaps.

${ }^{9}$ For example, as source of funds, the contribution of the foreign liabilities is limited and bond financing is small (2 per cent of total liabilities), causing an aggravation of the maturity mismatch between assets and liabilities in the GCC banking industry.
} 
Table 2 is a summary of empirical findings. The fit $\left(R^{2}\right)$ of the estimated equations of models 1, 2 and 3 is acceptable. The models explain almost 83 per cent of the variation in the dependent variable. The adjusted $\left(R^{2}\right)$ is lower, but it exceeds 80 per cent for the three models. The Hausman test value, with the $p$-value of the estimated Chi-Squire $\left(\chi^{2}\right)$ statistics is very low, helps to rejects the REM. This supports the choice of the FEM, indicating that the random error terms $\left(\varepsilon_{i}\right)$ are probably correlated with one or more of the regressors. Hence, in short, the FEM is preferred to REM.

As shown by the results from Model 3, the autonomous speed of diffusion is significantly different than zero, while the speed of diffusion is relatively slow for all countries under consideration. The time variable has a significant and negative sign, indicating that the usage of OBS businesses is decreasing over the test period suggesting lower adoption of OBS items. It indicates $\mathrm{OBS}$ businesses in the GCC region may be considered as risk increasing businesses rather than risk decreasing activities. This conclusion may be attributed to deficiency in the technological infrastructure and/or lower engagement in the speculation and hedging businesses within the market workplace. Or it could simply be the results of withdrawals from this activity post financial crisis.

At the bank-specific firm level, market power has a positive and significant impact, indicating that a bank with more market power would be categorized as more creditworthy, engendering such banks to underwrite an OBS item. The bank size has positive and significant impact, reflecting that there are economies of scale influence resulting from OBS businesses in the GCC region. This would help us to conclude the relative contribution of OBS businesses within the overall balance sheet products.

The loan ratio has a positive and significant impact on the OBS businesses in the GCC banking industry indicating that loans and OBS businesses are not substitutes. This indicates economies of scope between loans and OBS businesses as well. The result suggest that banks would issue more OBS products in order to minimize the resulting risk generated from loans. The net loan ratio has a positive and significant influence on OBS businesses. This indicates a tendency to making more risky loans, and reflects widening maturity mismatches between assets and liabilities causing more risk exposure to be hedged, thus leading to issuing an OBS products. 
Table 2: Estimated Results from fixed effect least squares dummy variable model (LSDV) with cross sectional weights

\begin{tabular}{|c|c|c|c|c|}
\hline \multicolumn{5}{|c|}{ 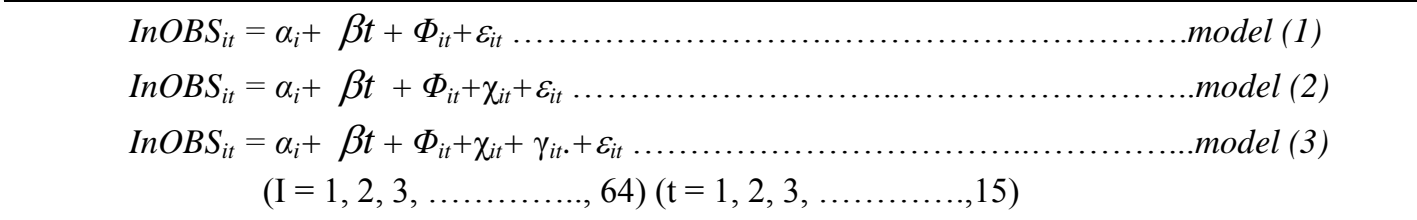 } \\
\hline Variable & \multicolumn{2}{|c|}{ Model (1) } & Model (2) & Model (3) \\
\hline Constant & \multicolumn{2}{|c|}{$\begin{array}{l}\text { 1939.21*** } \\
(1262.08)\end{array}$} & $\begin{array}{l}1939.29 * * * \\
(1256.46)\end{array}$ & $\begin{array}{l}\text { 1939.91*** } \\
(1207.39)\end{array}$ \\
\hline TIME & \multicolumn{2}{|c|}{$\begin{array}{l}-0.022 * * * \\
(-5.69)\end{array}$} & $\begin{array}{l}-\mathbf{0 . 0 1 0} * * * \\
\mathbf{( - 0 . 8 9 7 )}\end{array}$ & $\begin{array}{l}-0.015 * * \\
(-0.65)\end{array}$ \\
\hline MARP & \multicolumn{2}{|c|}{$\begin{array}{l}\mathbf{5 1 5 . 7 1} * * * \\
(8.39)\end{array}$} & $\begin{array}{l}523.56^{* * *} \\
(8.50)\end{array}$ & $\begin{array}{l}549.75 * * * \\
(8.74)\end{array}$ \\
\hline BSIZ & \multicolumn{2}{|c|}{$\begin{array}{l}9.41 * * * \\
(40.85)\end{array}$} & $\begin{array}{l}9.40 * * * \\
(40.73)\end{array}$ & $\begin{array}{l}9.29 * * * \\
(38.01)\end{array}$ \\
\hline LOAR & $3.36 * * *$ & $(2.75)$ & $\begin{array}{l}3.29 * * * \\
(2.70)\end{array}$ & $\begin{array}{l}3.77 * * * \\
(2.95)\end{array}$ \\
\hline NLOR & \multicolumn{2}{|l|}{$\begin{array}{l}2.66^{* *} \\
(2.05)\end{array}$} & $\begin{array}{l}2.71 * * \\
(2.08)\end{array}$ & $\begin{array}{l}2.18 * * \\
(1.61)\end{array}$ \\
\hline NCHR & \multicolumn{2}{|c|}{$1.98 * * *$} & $\begin{array}{l}1.97 * * * \\
(4.24)\end{array}$ & $\begin{array}{l}1.97 * * * \\
(4.27)\end{array}$ \\
\hline PROF & \multicolumn{2}{|l|}{$\begin{array}{l}-0.55 \\
(-0.20)\end{array}$} & $\begin{array}{l}-0.80 \\
(-0.28)\end{array}$ & $\begin{array}{l}-1.04 \\
(-0.36)\end{array}$ \\
\hline CAPC & \multicolumn{2}{|l|}{-} & $\begin{array}{l}0.009 \\
(0.71)\end{array}$ & $\begin{array}{l}0.01 \\
(0.80)\end{array}$ \\
\hline GROR & \multicolumn{2}{|l|}{ - } & - & 1.30 \\
\hline \multicolumn{2}{|l|}{$R^{2}$} & 0.832 & 0.832 & 0.829 \\
\hline \multicolumn{2}{|l|}{ Adjusted $R^{2}$} & 0.819 & 0.819 & 0.815 \\
\hline & 62.955 & 61.932 & 59.70 \\
\hline $\begin{array}{l}p \text {-value } \\
(F \text {-statistic) } \\
\text { Hausman tes } \\
\text { Ho: FEM vs }\end{array}$ & & 0.0000 & 0.0000 & 0.0000 \\
\hline Chi-Squire & tatistics & (6) 704.127 & (7) 703.623 & (8) 669.504 \\
\hline$p$-value & & 0.0000 & 0.0000 & 0.0000 \\
\hline Count. & & 946 & 946 & 946 \\
\hline
\end{tabular}

Explanatory notes: dependent variable is InOBS; $t$-statistics are reported in parentheses; $* * *$, **and *indicate significance at the 1, 5, and 10 percent level, respectively. Model (1) below presents the estimation of the banks' specific variables (creditworthiness variables) captured by $\Phi_{i t}$. Model (2) incorporates additional regulatory proxy affecting the OBS businesses captured by $\chi_{i t}$. Model (3) incorporates additional macroeconomic proxy affecting the OBS businesses captured by $\gamma_{i t}$. The three models are extracted basically from our formal model, equations 3 and 4 .

The net charge-off ratio has a significant and positive sign. The positive sign indicates that banks are using OBS businesses/products to manage loan portfolio risks, mainly risks that are normally result from bad debt. This suggests asset quality of the GCC banks has improved where banks are facing high credit growth rates and the non-performing loans to total loans have been 
declining since. Banks are asked by the prudential authorities to undertake substantial generous loan loss provisions against anticipation of continued increasing non-performing loans. The coverage ratio of provisions to non-performing loans across the GCC is very high by international standards: Hassan et al., 2010.

The profitability has a negative and insignificant impact on OBS businesses, indicating that higher OBS usage is not prompted by profitability considerations. Banks are earning high net interest income reflecting the deep emphasis on granting loans as traditional banking businesses and less prominence is given to fee-based forms as sources of income. Following the moral hazard hypothesis, the concentration risk of lending resulting from lending to few clients and/or lending to sectors that have high price exposure, creates the need to ask banks with high net interest income to lock in their interest spreads by using derivatives to hedge, while banks with low net interest income (low profitability) would use derivatives products to secure more profits. While the derivatives market in the region is still at its early stage of development, together with the fixed exchange rate regimes for the currencies of most GCC economies, low usage of derivatives to hedge or to speculate is obvious.

As shown by the $F$-statistics of Model 3, it seems that adding the two regulatory and macroeconomic variables does not significantly enhance the statistical fit of regression. The coefficients of capital adequacy and GDP growth are statistically insignificant, although both variables have positive signs as suggested by theory. It seems that banks with high capital ratio are less likely to engage in OBS businesses in order to avoid regulatory constraints, which supports the capital avoidance hypothesis - banks with low capital are more likely to engage in OBS businesses. This also helps to confirm that low regulatory pressure has positive impact on the use of OBS products. It indicates that low regulatory pressure increases creditworthiness of banks, and increases clients' incentives to engage in the OBS products offered by banks under consideration. ${ }^{10}$ This would have us argue that regulators imposing binding restrictions on bank

\footnotetext{
${ }^{10}$ In other words, low capital regulation, as implied by high CAR, signifies relevant capital position (high credit rating), reflecting more creditworthiness position of a bank, causing higher engagement in OBS businesses (Koppenhaver and Stover, 1991). Alternately, low capital regulation (low regulatory pressure) also reduces the marginal propensity to increase the risk of a banks' asset portfolio (Furlong and Keeley 1989, cited by Nachane and Ghosh 2007 and Khasawneh and Kabir 2010).Therefore, banks with high capital ratios (implying low regulatory pressure) can be expected to have lower OBS risk, and hence, engage in lower OBS businesses.
} 
capital will lead to the banks engaging in less OBS usage: a supporting for the argument that OBS businesses should be avoided as these businesses are risk-increasing.

One possible reason for this observation is that the impact of the regulatory variable (the capital adequacy ratio) may actually arise from the ground reality that GCC countries have their currencies fixed since 2003 to the major currency for reason of exchange rate stability. The domestic interest rates are largely a function of US dollar interest rates with variation of up to 30 basis points from time to time as country risk or transaction costs. Prudential authorities in the countries have concluded that this is an effective policy to deliver low price inflation, mainly for tradable commodities while it also enhances the credibility to the local currencies. While inflation positively correlated with the high oil prices that boosted incomes and local demand in these countries. However, it seems that the exchange rate pegging policy provides a level of stability to current prices and future price expectation makes such issue not to emerge as a problem: Gray and Blejer, (2006).

The insignificant impact of the macroeconomic factor on the OBS usage may indicate that higher real GDP growth does not necessarily cause an increase in the OBS usage. The positive impact of the real GDP growth on the OBS usage indicates that the OBS businesses follow the overall economic growth and business cycles. More economic growth would create more OBS usage, indicating the double role of the OBS businesses as income generating and risk management techniques. In other words, an upturn in the economic activities would increase business risks and there is an incentive to supply more volume of OBS businesses.

\section{Conclusions}

Earlier empirical research pertaining to off balance sheet business has documented evidence on countries where the phenomenon is prevalent in the developed banking markets. This paper is on several countries described as GCC countries reliant on oil revenue with pegged currencies. These countries may be described as emerging with lot less OBS activities, thus providing a converse environment to test some of the theories on what chases OBS activities to increase or 
retard in such emerging economies. The determinants included not only bank-specific variables but also regulation and macroeconomic conditions

The results appear to endorse a conclusion that the speed of diffusion of adopting off balance businesses by banks is relatively slow. The negative sign on the coefficient for time indicates decreasing trend overtime. It suggests a declining adoption of OBS businesses. Also, the estimates suggests that bank-specific variables such as market power, bank size, loan ratio, net loan ratio and net charge-offs ratio, all have theory-suggested positive impact on the dependent variable (OBS business activity). Insignificant negative impact is found for profitability. Results show insignificant influence from regulatory as well as the macroeconomic variables, although the impact is positive in both cases. The positive influence of the regulatory and macroeconomic variables supports the argument that prudential regulators, region-wide, need to be aware of the OBS adoption as financial innovations. We also suggest that the same forces are in play in the region as in other more active OBS places.

For the GCC banking industry, the low adoption of most OBS items can be justified. First, most bank businesses are directed towards on-balance sheet products in which the GCC banks would have significant concentration risk in the context of lending to few targeted clients and/or lending to sectors that have high price exposure (sectors that are subject to market price fluctuations and asset bubbles such as real estate and equities): Hassan et al. (2010). Second, on the level of capital markets, in spite of having an advanced infrastructure, most GCC capital markets have not yet started to provide derivative instrument/products such as stock futures, index futures, options, debt swaps, interest rate futures, and commodities futures. Accordingly there is deficiency in the offering many OBS products simply as a reflection of the (i) high profitability from normal on-balance activities and (ii) lack of willingness - perhaps because of the early stage of financial development or perhaps cultural norms towards risky OBS - of expertise in OBS structures. These things may change if the environment changes. Add to these, the other facts of (iii) good interest spreads in banks, and (iv) pegged currencies, it would be 
some time before OBS activities could pick up as it did in the developed economies. ${ }^{11}$ Gray and Blejer (2006).

There are some policy relevant findings. Given the heavy focus towards traditional banking activities, prudential authorities have to provide more focus towards banks asset/liability management practices, where banks need to re-evaluate their OBS positions as part of their overall liquidity management strategies, not so much OBS for securing fee incomes. This seems crucial given the tightening in the international liquidity positions in the current years. Second, there is a need for education and incentives to develop the derivatives to manage the liquidity risk of the balance sheet in the GCC region. Third, the influence of oil price effect on the banking profitability needs to be studied so as to see how OBS activities could be beneficial to offset risk on the balance sheet through OBS activities.

Author information: Mohammad Elian is an associate professor of finance, Department of Economics and Finance, Gulf University for Science and Technology (GUST), Kuwait. His address is Gulf University for Science and Technology, Mubarak Al-Abdullah Area/West Mishref, P.O. Box 7207, Hawali, Kuwait 22093. He may be contacted via e-mail: elian.m@gust.edu.kw.

\section{References}

Ahmad, K. and Hassan, K. (2010). The Determinants and policy Implications of Off-Balance Sheet Activities in MENA Countries Commercial Banks. Economic Research Forum, October, 1-31.

Angbazo, L. (1997). Commercial Banks Net Interest Margins, Default Risk, Interest Rate Risk and Off-Balance Sheet Banking. Journal of banking and Finance, 21, 55-87.

Ariff, M., Farrar, J., and Khalis, A., (2012). Regulatory Failure and the Global Financial Crisis. Edward Elgar Publishing, UK and USA.

Baer, H. and Pavel, C. (1987). Does Regulation Derive Innovation? Economic Perspective, Federal Reserve Bank of Chicago, 3-16.

Bennett, B. (1986). Off balance sheet risk in banking: the case of standby letters of credit. Economic Review, Federal Reserve Bank of San Francisco, issue Win, pages 19-29.

Benveniste, L. and Berger, A. (1987). Securitization with Recourse: An Instrument that Offers Uninsured Depositors Sequential Claims. Journal of Banking and Finance, 11, 403-424.

\footnotetext{
${ }^{11}$ For example, foreign exchange forward contracts against the US dollar are not used under the expectation that the exchange rate will not change in the future, however, foreign exchange forward contracts against the euro and other currencies are needed. Further, other complex derivatives products such as futures and options can be used throughout the liquid US markets without facing exchange rate risks, reflecting an advantage of the monetary policy decision to peg the exchange rate by allowing an effective outsourcing.
} 
Bondt, G. (1997). Off-Balance Sheet Diffusion: European Evidence from Bank-Level Data. Onderzoeksrapport WO\&E nr 528/9743, December, 1-14.

Boyd, J. and Gertler, M. (1994). Are banks dead? Or are the reports greatly exaggerated? Federal Reserve Bank of Minneapolis Quarterly Review 18, 1-27.

Edwards, F. and Mishkin, F. (1995). The Decline of Traditional Banking: Implications for Financial Stability and Regulatory Policy. NBER Working Paper, w4993, 1-31.

Fung, M. and Cheng, A. (2004). Diffusion of Off-Balance Sheet Financial Innovation: Information Complementary and Market Competition. Pacific-Basin Finance Journal, $12,525-540$.

Furlong, F. and Keeley, M. (1989). Capital Regulation and Bank Risk-Taking. Journal of Banking and Finance, 35, 883-891.

Hannan, T. and McDowell, J. (1984). Rival Precedence and the Dynamics of Technology Adoption: An Empirical Analysis. Journal of Economics and Business, 49, 533-547.

Jagtiani, j., Saunders, A. and Udell, G. (1995a). The Effect of Bank Capital Requirement on Bank Off-Balance Sheet Financial Innovation. Journal of Banking and Finance, 19, 647658.

Jagtiani, j., Nathan, A. and Sick, G. (1995b). Scale Economies and Cost Complementarities in Commercial Banks: On and Off-Balance Sheet Activities. Journal of Banking and Finance, 19, 1175-1189.

Hassan, K. and Sackley, W. (2002). Determinants of the US saving and loan off-balance sheet activities: an empirical investigation. Finance India: the quarterly journal of Indian Institute of Finance. 16, 3, p. 915-931

Gray, S. and Blejer, M. (2006). The Gulf Cooperation Council Region: Financial Market Development, Competitiveness, and Economic Growth. IMF, 1.4, 41-51.

Al-Hassan, A., Khamis, M. and Oulidi, N. (2010). The GCC Banking Sector: Topography and Analysis. IMF Working Paper, 10/87, 1-37.

Kaufman, G. and Mote, L. (1994). Is Banking A Declining Industry? A Historical Perspective. Federal Reserve Bank of Chicago, Economic Perspective, May/June, 2-21.

Khambata, D. and Bagdi, R. (2003). Off-Balance Sheet Credit Risk of the Opt 20 Japanese Banks. Journal of International Business Regulation, 5, 57-71.

Koppenhaver, G. (1989). The Effects of Regulation of Bank Participation in the Guarantee Market. Research in Financial Services, 1, 165-180.

Koppenhaver, G. and Stover, R. (1989). Standby Letter of Credit and Large Bank Capital: An Empirical Analysis s. Journal of Banking and Finance, 15, 315-327.

Morrison, J. (1996). How to Use Diffusion Models in New Product Forecasting. The Journal of Business Forecasting, Summer, 6-9.

Nachane, D. and Ghosh, S. (2002). Determinants of Off-Balance Sheet Activities: An Empirical Analysis of Public Sector Banks. Economic and Political Weekly, Special Issue in Money, Banking and Finance, February, 421-428.

Nachane, D. and Saibal, G. (2007). An Empirical Analysis of the Off-Balance Sheet Activities of Indian Banks. Munich Personal RePEc Archive (MPRA), Paper No. 17304. Online at http://mpra.ub.uni-muenchen.de/17304.

Pavel, C. and Philis, D. (1987). Why commercial Banks Sell Loans: An Empirical Analysis. Economic Perspective, Federal Reserve Bank of Chicago, June, 3-14. 
Siems, T. and Clark, J. (1997). Rethinking Bank Efficiency and Regulation: How Off-Balance Sheet Activities Make a Difference. Financial Industries Studies, Federal Reserve Bank of Dallas.

Sinha, R. (2005). Off Balance Sheet Exposure of Indian Commercial Banks: Some Empirical Results. Indian Institute of Capital Markets, the $9^{\text {th }}$ Capital Markets Conference. Available at http://ssrn.com/abstract=977813. 